\title{
Two Visual Processing Pathways Are Targeted by Gonadotropin-Releasing Hormone in the Retina
}

\author{
Kerry E. Grens ${ }^{a}$ Anna K. Greenwood ${ }^{b}$ Russell D. Fernalda,b \\ ${ }^{a}$ Department of Biological Sciences, and ${ }^{\mathrm{b}}$ Neurosciences Program, Stanford University, Stanford, Calif., USA
}

\section{Key Words}

Terminal nerve $\cdot$ Teleost $\cdot$ Amacrine cell $\cdot$ Retinal ganglion cell $\cdot \mathrm{GNRH} \cdot$ Receptor $\cdot$ Fish

\begin{abstract}
In fish the terminal nerve is comprised of a group of cells with somata adjacent to the olfactory bulb and processes that extend both anteriorly to the olfactory mucosa and posteriorly to the telencephalon. In teleost fish an additional group of axons extends along the optic tract and delivers putative neuromodulators to the retina. One peptide-gonadotropin-releasing hormone ( $\mathrm{GnRH})$ - has been implicated as a prime candidate neuromodulator based on electrophysiological evidence that exogenous application influences neural activity. Here we describe the expression patterns of two $\mathrm{GnRH}$ receptor subtypes in the retina of a teleost fish, Astatotilapia (Haplochromis) burtoni. The type $1 \mathrm{GnRH}$ receptor (GnRH-R1) was expressed in cells of the amacrine cell layer - where lateral inputs affect the flow of visual information from photoreceptors to the brain - and in a distribution and location pattern similar to dopaminergic interplexiform cells. Immunohistochemical labeling of $\mathrm{GnRH}$ fibers revealed varicosities along terminal nerve axons near the amacrine cell layer and near cells immunoreactive for tyro-
\end{abstract}

\section{KARGER}

Fax +4161306 1234

E-Mail karger@karger.ch

www. karger.com

\section{(c) 2005 S. Karger AG, Basel}

Accessible online at: www. karger.com/bbe sine hydroxylase, a dopaminergic cell marker. This finding supports an existing model that the terminal nerve forms synapses with dopaminergic interplexiform cells. Surprisingly, the type $2 \mathrm{GnRH}$ receptor (GnRH-R2) was abundantly expressed in ganglion cells, which lie along the direct pathway of visual information to the brain. These data suggest that $\mathrm{GnRH}$ from the TN could broadly influence processing of retinal signals both in lateral processing circuits through GnRH-R1 and in the vertical throughput pathway through $\mathrm{GnRH}-\mathrm{R} 2$.

Copyright @ 2005 S. Karger AG, Basel

\section{Introduction}

Although described in every class of vertebrates [see Demski, 1993 for review] with few exceptions [Eisthen and Northcutt, 1996], little is understood about the function of the 0th cranial or 'terminal' nerve. The terminal nerve (TN) was originally thought to participate in sensory functions based on lesion studies and its conspicuous anatomical relationship to olfactory and visual processing areas [Demski and Northcutt, 1983]. Now the TN is viewed as a neuromodulator of forebrain, retinal, and olfactory information processing [Oka, 1992; Eisthen et al., 2000]. Typically in fish the TN has cell bodies located 
near the olfactory bulb and sends central processes into the telencephalon and peripheral processes toward the olfactory mucosa, although its precise anatomy varies widely among species [Demski, 1984]. Where described in teleost fish, TN cell axons travel with the optic nerve and arborize in the inner plexiform layer of the retina [Munz et al., 1982; Stell et al., 1984]. Retinal projections of the TN have also been reported for the northern leopard frog [Wirsig-Wiechmann and Basinger, 1988], although the neuroanatomy in this species is less well characterized.

By convention, the terminal nerve is identified by its location and by its immunoreactivity to gonadotropinreleasing hormone $[\mathrm{GnRH}$, also called luteinizing-hormone releasing hormone (LHRH)]. There are several forms of GnRH expressed in the brains of vertebrate species, each encoded by distinct genes and referred to as class 1, 2, or 3 [Fernald and White, 1999]. In each species, the particular peptide sequence varies, but the anatomical location and some functions are conserved. GnRH1 is the signaling peptide used by neurons that project from the forebrain to the pituitary where it regulates gonadotropin release [White et al., 1995]. GnRH2 is found in the midbrain near the fourth ventricle [White et al., 1995] and has been shown to act as a neuromodulator in spinal neurons [Jan et al., 1980]. A third form, GnRH3, is localized in the terminal nerve [White et al., 1995; Dubois et al., 2002].

The teleost retina is an ideal system in which to study TN function; cell types are readily identifiable and connections between cell layers have been described in great detail [see fig. 1A for a schematic of the teleost retina; Dubin, 1974]. Electron microscopic images have shown that GnRH-immunoreactive fibers of the TN synapse on dopaminergic cells of the goldfish retina [Zucker and Dowling, 1987]. These dopaminergic interplexiform cells comprise about $1 \%$ of cells in the amacrine cell layer of goldfish [Marc, 1982] and send processes distally to the outer plexiform layer and proximally to the inner plexiform layer [Dowling and Ehinger, 1978]. Others have found evidence of TN fibers adjacent to ganglion, bipolar, amacrine, and horizontal cells [Stell et al., 1984; Ball et al., 1989; Malz et al., 1999].

Although no published reports have described electrophysiological recordings from dopaminergic cells during application of $\mathrm{GnRH}$, horizontal and ganglion cells have been investigated and implicated as possible targets because they show electrical responses to GnRH application. Walker and Stell [1986] recorded from retinal ganglion cells in the goldfish and found that GnRH was usually excitatory. Based on anatomical connections and the effects that peptides had during light responses, the researchers proposed that amacrine and possibly horizontal cells are targets of neuromodulators released from the $\mathrm{TN}$, although they could not exclude ganglion cells as well. Umino and Dowling [1991] provided further electrophysiological evidence that GnRH from the terminal nerve affects dopaminergic and possibly amacrine cells. Their recordings from horizontal cells showed that GnRH application mimicked the action of dopamine. Because the interplexiform cells are thought to be the only dopaminergic cells in the goldfish retina [Dowling and Ehinger, 1978], this suggested that GnRH from the TN elicits dopamine release by directly acting on dopaminergic cells or indirectly via amacrine cells.

Electrophysiological recordings support the idea that GnRH can modulate retinal activity but, due to the interconnected nature of the retina, it has not been possible to identify specifically where and how GnRH acts. To understand how GnRH might act on retinal circuitry, we need to know where GnRH receptors are located. We have previously shown that the teleost fish Astatotilapia (Haplochromis) burtoni possesses two types of GnRH receptors, type 1 and type 2 [Robison et al., 2001; Au et al., 2003]. Lethimonier et al. [2004] provided a basis for characterizing GnRH receptors as type 1 or type 2 based on predicted molecular phenotypes, and A. burtoni has been shown to express GnRH-receptor type 2 (GnRH-R2; note that Lethimonier and colleagues list this receptor in A. burtoni as GnRH-R1) in the retina [Robison et al., 2001]. Madigou et al. [2000] also reported finding a type 2 GnRH receptor in the retina of rainbow trout (Oncorhynchus mykiss). The expression of the type 1 receptor in the retina has not yet been described. To establish which receptors are responsible for detecting $\mathrm{GnRH} 3$ from the $\mathrm{TN}$ and which cell types could respond to GnRH3, we performed in situ hybridization to the type 1 and type 2 GnRH receptor mRNA in the A. burtoni retina. We also localized GnRH-expressing terminal nerve fibers in A. burtoni using immunohistochemistry. Our findings illuminate the pathways employed by GnRH3 to affect visual processing in the retina and provide a foundation for further studies of such modulation. Furthermore, these results lend insight into GnRH ligand-receptor relationships.

\section{Materials and Methods}

To identify potential retinal targets of GnRH from the terminal nerve we (1) examined the location of GnRH immunoreactivity in the retina and (2) localized GnRH receptors to specific retinal cell 
types. For the first study, we labeled TN fibers with an antibody to GnRH3 and, because TN fibers and dopaminergic cells are thought to form synaptic connections [Zucker and Dowling, 1987], we performed a double antibody stain with GnRH3 and tyrosine hydroxylase $(\mathrm{TH})$, a dopaminergic cell marker. Although TH labels all catecholaminergic cells, only dopaminergic cells have been identified in fish retinas [Dowling and Ehinger, 1978]; therefore we will refer to TH-positive cells as dopaminergic. For the second study we performed in situ hybridization to detect mRNA of GnRH receptor subtypes 1 and 2 in retinal sections.

\section{Tissue Preparation}

Reproductively active male $A$. burtoni were selected from a general laboratory population derived from a wild-caught stock. All handling of fish was in accordance with the policies of the Stanford University Administrative Panel on Laboratory Animal Care. Animals were killed by rapid cervical transection and enucleated eyes were placed in sterile phosphate-buffered saline (PBS). The cornea, lens, and in some cases sclera were removed and the vitreous humour digested by a $5 \mathrm{~min}$ incubation in $200 \mathrm{U} / \mathrm{ml}$ hyaluronidase in PBS. Eyes used for immunohistochemistry on retinal sections were fixed overnight in $4 \%$ paraformaldehyde at $4{ }^{\circ} \mathrm{C}$, cryoprotected in $30 \%$ sucrose with $0.02 \%$ sodium azide for $24 \mathrm{~h}$, embedded in OCT Compound (Tissue-Tek, Torrence, Calif., USA), and stored at $-80^{\circ} \mathrm{C}$ until they were serially sectioned at $20 \mu \mathrm{m}$ using a cryostat and thawmounted onto slides (Superfrost, Fisher, Santa Clara, Calif., USA) Eyes used for immunohistochemistry on whole retinas were dissected and fixed as above and an additional dissection was performed to remove the cornea, iris, sclera, choroid and pigmented epithelium [Zygar et al., 1999], and retinal cups were stored at $4{ }^{\circ} \mathrm{C}$ in PBS until use. Eyes used for in situ hybridization were immediately embedded after vitreous digestion, flash-frozen and stored at $-80^{\circ} \mathrm{C}$ until they were serially sectioned at $14 \mu \mathrm{m}$ on a cryostat and thaw-mounted onto glass slides (Superfrost, Fisher, Santa Clara, Calif., USA). Slides were stored at $-80^{\circ} \mathrm{C}$ until use.

\section{Immunohistochemistry}

Immunohistochemistry was performed on both retinal sections and whole-mounted retinas in order to locate GnRH3-containing TN fibers. Immunohistochemical processing of retinal sections was as follows: $5 \mathrm{~min}$ in phosphate buffered saline (PBS), $5 \mathrm{~min}$ in PBS supplemented with $0.2 \%$ bovine serum albumin and $0.2 \%$ Triton X-100 (PBT), $1 \mathrm{~h}$ in PBT with $5 \%$ normal goat serum (Pel-Freeze, Rogers, Ark., USA), overnight incubation with primary antibody diluted 1:1000 in PBT with $5 \%$ normal goat serum at $4^{\circ} \mathrm{C}$. Primary antibody was generously provided by Dr. Kobayashi (University of Tokyo) and is a polyclonal rabbit antibody against $\left[\operatorname{Trp}^{7}\right]\left[\mathrm{Leu}^{8}\right]-\mathrm{GnRH}$, which is the GnRH3 form in A. burtoni [White et al., 1995]. Following primary antibody incubation, slides were washed four times for 15 min each in PBT and incubated at room temperature for $2 \mathrm{~h}$ with biotinylated anti-rabbit antibody diluted 1:200 in PBT (Vector Laboratories, Burlingame, Calif., USA). Slides were then washed four times for $15 \mathrm{~min}$ each in PBT and incubated at room temperature for $2 \mathrm{~h}$ with Texas Red-conjugated avidin diluted 1:200 in PBS (Vector Laboratories) and Hoechst 33342 diluted 1:1000 for nuclear staining (Sigma, St. Louis, Mo., USA). Slides were washed in PBS and coverslipped in Fluoromount-G mounting media (Southern Biotechnology Association, Birmingham, Ala., USA). For whole-mounted retinas, the steps were performed in vials with incubations and reagents as described above, except that antibody incubation times were in- creased and Triton X-100 was used at a concentration of $0.5 \%$ instead of $0.2 \%$. Following the procedure, several slits were made in the eye cup so that the retina could be mounted flat on a microscope slide [Zygar et al., 1999].

To locate dopaminergic interplexiform cells we immunostained for tyrosine hydroxylase (TH) alone and in combination with $\mathrm{GnRH}$ immunohistochemistry. The single $\mathrm{TH}$ antibody stain procedure was performed as above, except for the following modifications: primary antibody was monoclonal mouse anti-TH diluted 1:500 (Chemicon, Temecula, Calif., USA), secondary antibody was peroxidase-conjugated anti-mouse (Vector Laboratories), and fluorescent conjugate was added using tyramide signal amplification as follows. Briefly, following secondary incubation, slides were washed twice in PBT, incubated for $10 \mathrm{~min}$ in fluorescein tyramide reagent diluted 1:50 in amplification diluent (TSA Direct Kit, Perkin Elmer, Wellesley, Mass., USA), washed twice in PBT and then incubated with the nuclear stain Hoechst 33343 as above. For detection of both TH and $\mathrm{GnRH}$, the primary and secondary antibodies were simply combined. For the TH stain in whole retinas, the secondary antibody was biotinylated anti-mouse and the tertiary was Texas Red-conjugated avidin, both diluted 1:200 (Vector Laboratories). Double staining was not performed in whole retinas.

\section{In situ Hybridization}

Templates for radioactively labeled RNA probes specific for GnRH receptor types I and II were generated using polymerase chain reaction (PCR). Primers specific to each GnRH receptor subtype were designed from known sequences of $\mathrm{GnRH}$ receptors in $A$. burtoni [GnRH-R1 GenBank Accession No. AF356598; GnRH-R2 GenBank Accession No. AY028476; note that the names of these sequences have changed to conform to the suggestions of Lethimonier et al., 2004]: primers for GnRH-R1: 5'-AATGAACGCCTCTCTGTGTGACCCTGC and 5'-GCCCAGCAGGTAGTATGGAGTCCAGCA; primers for GnRH-R2: 5'-AGAACAGAGGAGTCCGACCTGAGGCG and 5'-TGGTTGTTGGTGGAGGGCTGCG. Pituitary RNA was extracted and reverse transcribed using standard techniques and used for template amplification in a PCR Express Thermocycler (Hybaid, Waltham, Mass., USA). We used the Advantage-GC PCR Polymerase Mix (BD Biosciences, Palo Alto, Calif., USA) for PCR. An 800 bp PCR product for GnRH-R1 and an $1,100 \mathrm{bp}$ product for GnRH-R2 were cloned into the pCRII-TOPO vector using the TOPO TA Cloning Kit (Invitrogen, Carlsbad, Calif., USA). Plasmids from selected bacterial colonies were excised using a QIAspin MiniPrep Kit (QIAGEN, Valencia, Calif., USA) and sequenced. Plasmids were linearized using Bam $\mathrm{HI}$ and Xho I to generate both sense and antisense templates for each receptor and cleaned via QIAquick PCR Purification Kit (QIAGEN, Valencia, Calif., USA). Radioactive sense and antisense RNA probes were prepared using in vitro transcription with SP6 or T7 polymerase and ${ }^{35} \mathrm{~S}-\mathrm{UTP}$ according to manufacturer's directions (Maxiscript kit, Ambion, Austin, Tex., USA).

Retinal tissue slides were prepared for hybridization by a $10 \mathrm{~min}$ fixation in 4\% paraformaldehyde in PBS, rinsed twice for 3 min each in PBS, immersed in $0.1 M$ triethanolamine (TEA) buffer for $3 \mathrm{~min}$, acetylated in $0.25 \%$ acetic anhydride in $0.1 M$ TEA for $10 \mathrm{~min}$, rinsed twice for 3 min each in $2 \times$ sodium citrate sodium chloride (SSC) buffer, dehydrated in an ethanol series, and air dried. Probes were diluted to $5 \times 10^{6} \mathrm{cpm} / \mathrm{ml}$ in hybridization buffer (SigmaAldrich, St. Louis, Mo., USA) supplemented with $10 \mathrm{~m} M$ dithiothreitol (DTT). Preheated probe was distributed on each slide, slides 
were coverslipped, and hybridization occurred overnight in a $60^{\circ} \mathrm{C}$ mineral oil bath. Mineral oil was removed from slides by immersion in chloroform, and unbound and non-specifically hybridized probe was removed by two rinses in $4 \times \mathrm{SSC}$ (coverslips were removed during second rinse), $10 \mathrm{~min}$ in $2 \times \mathrm{SSC}$ with $10 \mathrm{~m} M$ DTT, $30 \mathrm{~min}$ in $10 \mu \mathrm{g} / \mathrm{ml}$ RNAse A in $2 \times$ SSC, $10 \mathrm{~min}$ in $2 \times$ SSC with DTT, $1 \mathrm{~h}$ in $50 \%$ formamide and $2 \times \mathrm{SSC}$ with DTT at $60^{\circ} \mathrm{C}$, two- 30 min washes in $0.1 \times \mathrm{SSC}$ at $60^{\circ} \mathrm{C}, 5 \mathrm{~min}$ in $0.1 \times \mathrm{SSC}$ at room temperature, and finally dehydrated in an ethanol series. Slides were dipped in nuclear emulsion (NBT-2; Eastman Kodak) diluted 1:1 in water, air dried, and stored light-free at $4{ }^{\circ} \mathrm{C}$ for two to three weeks. Exposed slides were processed as follows: 4 min in Kodak D-19 Developer (Eastman Kodak), briefly rinsed in water, 6 min in Kodak Fixer (Eastman Kodak), and rinsed in water. Following emulsion development, slides were stained with cresyl violet, dehydrated in ethanol, immersed in xylenes, and coverslipped with Permount mounting medium (Fisher Scientific, Santa Clara, Calif., USA).

\section{Microscopy}

Photomicrographs were taken on a Zeiss Axioscope (Zeiss, Thornwood, N.Y., USA) and recorded digitally using a Spot camera and associated software (Diagnostic Instruments, Sterling Heights, Mich., USA). Images were adjusted to enhance brightness and contrast. In situ hybridization signal was viewed and photographed under both brightfield and darkfield illumination. Brightfield and darkfield images were merged to show both tissue staining and silver grains above cells containing radioactive probe. Our criterion for a labeled cell was a cluster of $>10$ silver grains in a $10 \mu \mathrm{m}$-diameter circle, as background in areas without cell bodies typically contained less than this density of silver grains. Immunoreactivity was viewed and photographed under fluorescent illumination. Images for dual or triple fluorescent wavelengths were also merged to show nuclear staining and immunoreactivity simultaneously.

\section{Results}

\section{GnRH Fibers in the Retina}

Terminal nerve fibers in $A$. burtoni retinas were labeled using an antibody to GnRH3. Varicose fibers extended along the length of the inner plexiform layer (IPL) in close proximity to the amacrine cell layer of the inner nuclear layer (INL; fig. 1A). Some fibers extended into the INL, although none were observed to delve more than two cell layers deep (fig. 1B). In whole, flat-mounted retinas, fibers radiated perpendicular from the optic nerve tract and extended across the retina [data not shown; see Kawamata et al., 1990 for similar results]. Though fibers frequently crossed paths and occasionally ran dorso-ventrally, in general they coursed in a naso-temporal bearing. Fibers hovered just proximal (vitreal) of the INL and inhabited a narrow corridor of roughly $10 \mu \mathrm{m}$ from the edge of the INL into the IPL. Occasionally fibers dipped into planes of INL cells (fig. 1B). No labeling was evident in or near the ganglion cell layer (fig. 1C). Rather, the TN appeared to diverge from the optic nerve at the level of the IPL, and en passant GnRH-positive fibers near the GCL were therefore not observed. Negative controls, which lacked the primary antibody, were not stained (data not shown).

\section{GnRH Receptor Subtypes Are Expressed in Different Cell Types}

GnRH-R 1 . In situ hybridization revealed that the type 1 receptor mRNA was expressed in cells in the amacrine cell layer as demonstrated by the presence of distinct clusters of silver grains above a subset of cells in the vitreal INL (fig. 2A, C). GnRH-R1-expressing cells represented only a small percentage of the amacrine cell layer, roughly estimated to be between one and five percent, and were spread somewhat evenly throughout the retina and with no obvious pattern. Signal appeared above cells one or two cell layers scleral of the IPL. The negative control, which was a sense probe made to GnRH-R1 mRNA, showed only random, low-level silver grain placement (fig. 2B).

Fig. 1. Localization of gonadotropin releasing hormone $(\mathrm{GnRH})$ in the retina. Schematic illustration of a retinal cross section shows three parallel layers of cell nuclei separated by two plexiform layers. A, B, C Immunohistological staining of fibers containing $\mathrm{GnRH} 3$ fibers (red) with cell nuclei stained in blue. A Cross section of a retina showing varicose terminal nerve fibers immunoreactive to GnRH3 in the IPL (arrows) adjacent to the amacrine cell layer of the INL. Bar $=100 \mu \mathrm{m}$. B Higher magnification of the IPL/INL interface, showing fibers entering the amacrine cell layer. Bar $=10 \mu \mathrm{m}$. C Higher magnification of the ganglion cell layer showing a lack of fibers near this layer. $\mathrm{Bar}=50 \mu \mathrm{m}$. Images were contrast enhanced. $\mathrm{P}=$ Photoreceptors; $\mathrm{H}=$ horizontal cells; $\mathrm{B}=$ bipolar cells; $\mathrm{A}=$ amacrine cells; $\mathrm{G}=$ ganglion cells; $\mathrm{ONL}=$ outer nuclear layer; $\mathrm{INL}=$ inner nuclear layer; $\mathrm{IPL}=$ inner plexiform layer; $\mathrm{GCL}=$ ganglion cell layer.

Fig. 3. Tyrosine hydroxylase-positive cells in the retina. A Wholemounted retina showing cells immunoreactive for tyrosine hydroxylase (red). Cells were distributed across the retina within the amacrine layer in a somewhat regular pattern. Bar $=100 \mu \mathrm{m}$. B Cross section of a retina showing immunoreactivity to tyrosine hydroxylase (green). Cells comprised a small percentage of the amacrine cell layer in a sparse distribution (arrows), very similar to GnRH-R1 expression. Nuclear staining in blue. $\mathrm{ONL}=$ Outer nuclear layer; $\mathrm{INL}=$ inner nuclear layer; GCL = ganglion cell layer. Bar $=100 \mu \mathrm{m}$. C Double labeled section with antibodies to tyrosine hydroxylase (green) and GnRH3 (red) showing a dopaminergic cell with its process extending toward the inner plexiform layer. Terminal nerve fibers immunoreactive for GnRH3 extend toward the dopaminergic cell. Nuclear staining in blue. Bar $=10 \mu \mathrm{m}$. Images were contrast enhanced. 

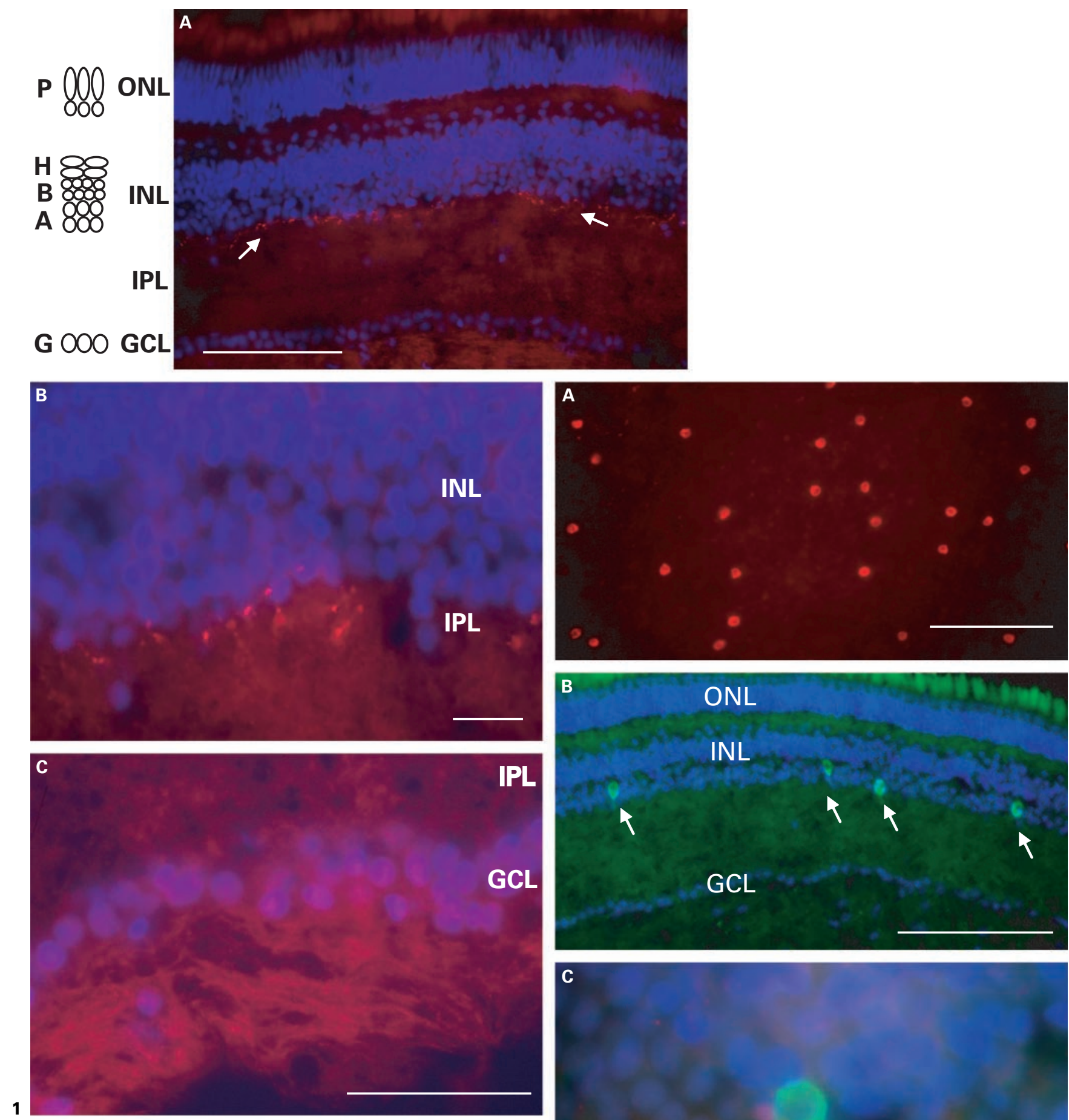

C

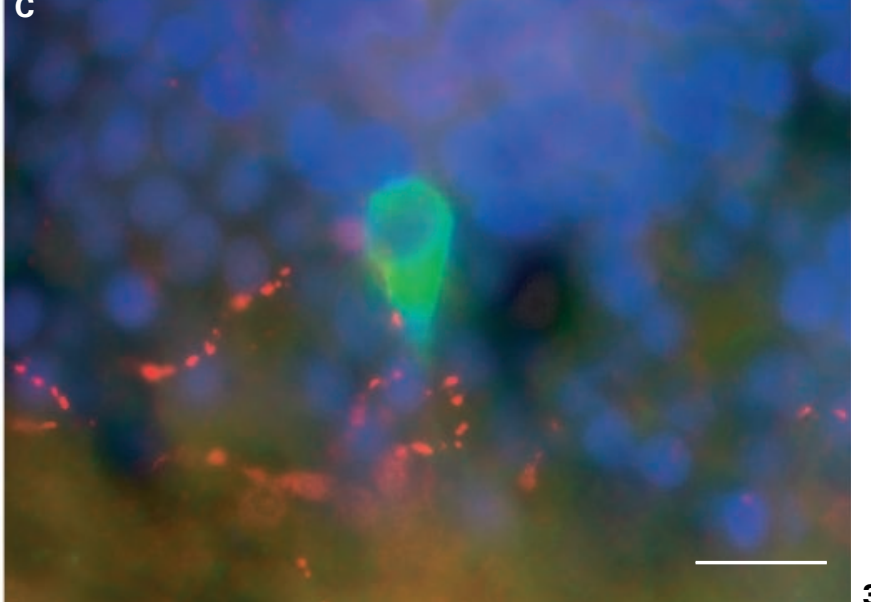



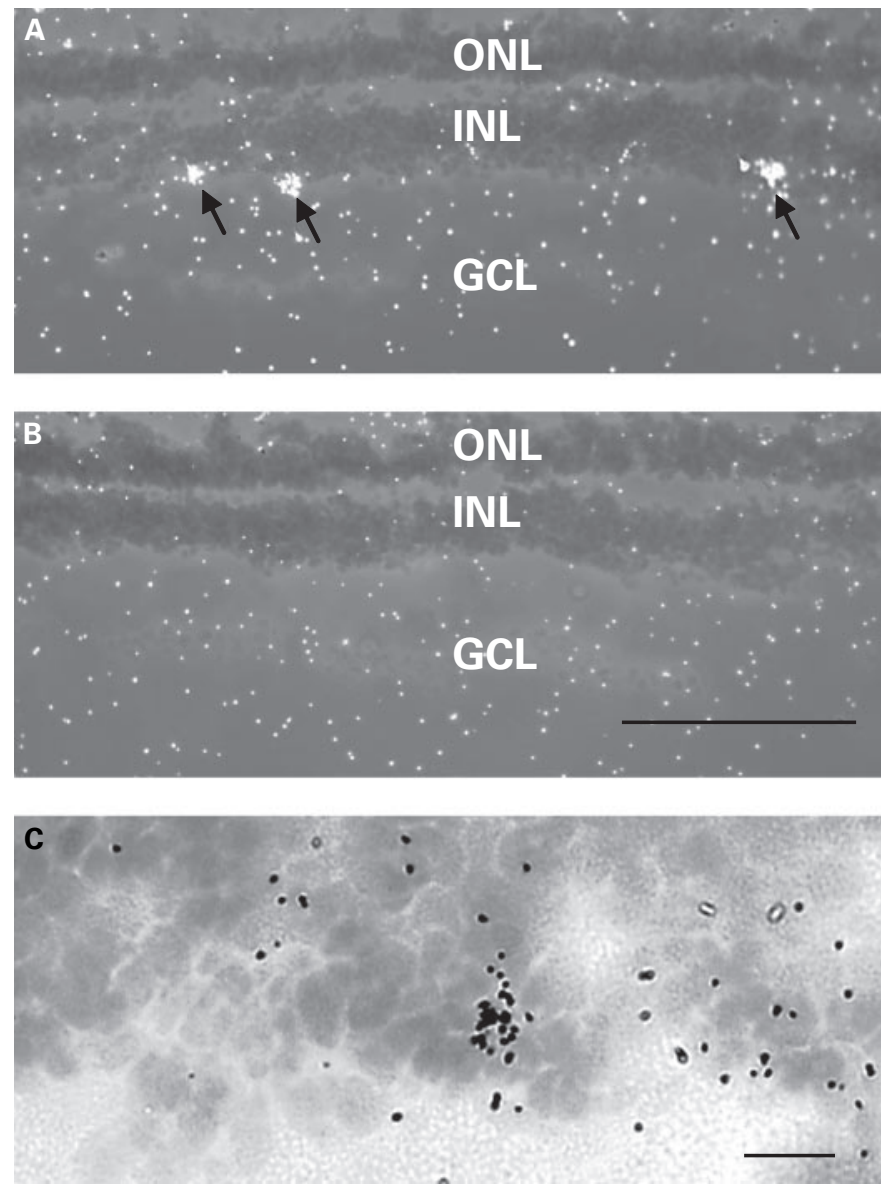

Fig. 2. GnRH receptor type 1 expression pattern in the retina. A In situ hybridization with a probe against GnRH-R1 mRNA revealed that a small percentage of cells in the amacrine cell layer with a sparse distribution (arrows) express GnRH-R1 as shown by densely clustered silver grains. B In situ hybridization with negative control sense probe for GnRH-R1 shows no specific staining. Bar $=100 \mu \mathrm{m}$. C Typical signal cluster over a single cell in the amacrine cell layer of the INL. Bar $=10 \mu \mathrm{m}$. ONL = Outer nuclear layer; $\mathrm{INL}=$ inner nuclear layer; $\mathrm{GCL}=$ ganglion cell layer. Images were contrast enhanced.

Cells expressing GnRH-R1 and cells immunoreactive for tyrosine hydroxylase exhibited a very similar distribution. TH antibody labeled a small percentage of cells in the amacrine cell layer, and, as seen in whole-mounted retinas, these cells were distributed throughout the retina but not in a geometric mosaic (fig. 3A). These cells constituted approximately $1 \%$ of the amacrine cell layer. These dopaminergic cells typically inhabited the second cell layer distal (scleral) to the IPL in the INL (fig. 3B) and had thick processes extending proximally toward the IPL
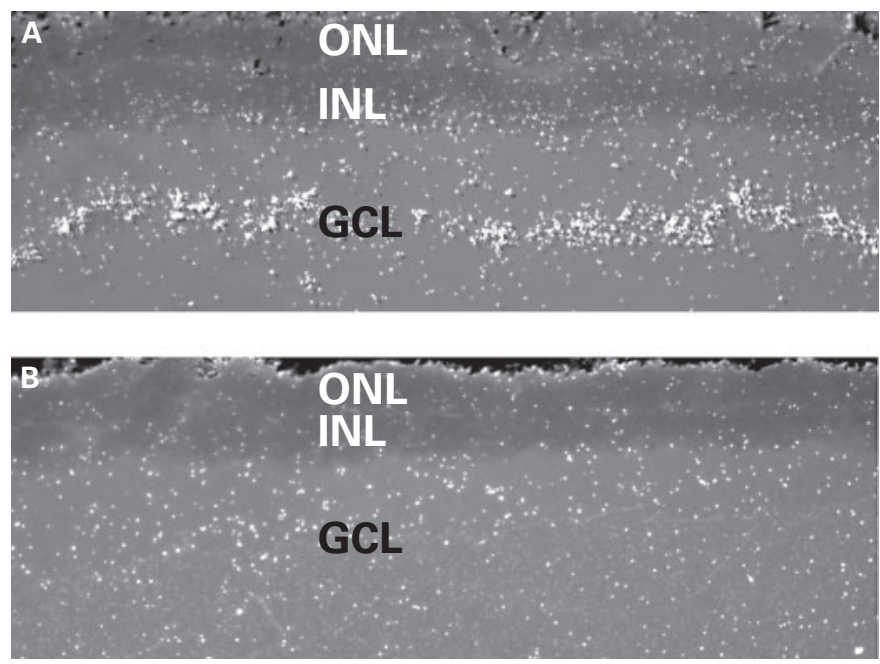

Fig. 4. GnRH receptor type 2 expression in the retina. A In situ hybridization to GnRH-R2 mRNA revealed widespread expression in the ganglion cell layer (GCL). B Negative control shows no signal pattern. $\mathrm{INL}=$ Inner nuclear layer; $\mathrm{ONL}=$ outer nuclear layer. $\mathrm{Bar}=$ $100 \mu \mathrm{m}$. Images were contrast enhanced.

(fig. 3C). When sections were double-labeled for TH and GnRH3, varicose GnRH immunoreactive fibers appeared adjacent to labeled cells, although varicosities were present along the whole INL/IPL border (see fig. 1B). Negative controls, without the primary antibody for tyrosine hydroxylase, exhibited no labeling (data not shown).

GnRH-R2. The type 2 receptor mRNA was expressed in cells in the ganglion cell layer (fig. 4A). The in situ hybridization signal was extremely abundant, and it appeared that most, if not all, cells in this layer expressed GnRH-R2. The negative control sense probe produced no such signal (fig. 4B).

\section{Discussion}

Our description of $\mathrm{GnRH}$ immunoreactivity and GnRH receptor expression paints a more definitive picture of where GnRH delivered by the TN could act in the retina of a teleost fish. We have shown that both GnRH receptor types were expressed in the retina and that each is expressed in a different class of cell - type 1 is expressed in a small percentage of cells in the amacrine cell layer, and type 2 is ubiquitously expressed in the ganglion cell layer. 
The type 1 receptor expression data support the model by Zucker and Dowling [1987] that TN fibers synapse on dopaminergic interplexiform cells in the amacrine cell layer. Our data showed that cells expressing the type 1 receptor and dopaminergic cells exhibited a similar location and distribution pattern. Moreover, GnRH immunoreactive $\mathrm{TN}$ fibers were adjacent to the amacrine cell layer and at times extended into this layer, while dopaminergic cells extended processes toward the IPL. We propose that it is the dopaminergic cells that express GnRH-R1. However, without confirmation by doublelabeling, the possibility remains that non-dopaminergic amacrine cells express GnRH-R1 [Kawamata et al., 1990]. Marc [1982], for example, quantified other cell types in the amacrine cell layer that have a similar distribution as we have shown for GnRH-R1: GABAergic amacrine cells comprise about $2 \%$ of the amacrine cell layer, and indoleaminergic cells about $1 \%$. Ball et al. [1989] showed that TN processes appear to make contact with GABAergic amacrine cells, among others. The proposition that type $1 \mathrm{GnRH}$ receptor is expressed in dopaminergic cells is still the most attractive scenario given Umino and Dowling's finding that horizontal cells respond to GnRH application by mimicking the effects of dopamine, suggesting that GnRH acts through dopaminergic interplexiform cells to stimulate dopamine release [Umino and Dowling, 1991]. This hypothesis rests on tyrosine hydroxylase and GnRH-R1 protein being colocalized to the same cells.

The distribution of the type $2 \mathrm{GnRH}$ receptor is quite surprising as retinal ganglion cells were not previously considered a direct target for GnRH3, but rather electrophysiological responses recorded in those cells were believed to reflect a downstream response to activity in interplexiform neurons [Walker and Stell, 1986]. Indeed, retinal ganglion cells are downstream targets of $\mathrm{GnRH}$, as dopaminergic and amacrine cells act upstream of ganglion cells [Dowling and Ehinger, 1978]. However, in addition, we find that the type 2 receptor is widely distributed in the ganglion cell layer. In light of our findings, it is likely that Walker and Stell may have recorded combined effects from both a direct and downstream GnRH target: the retinal ganglion cell. It is unclear whether the receptor might also be expressed in displaced amacrine cells as well as ganglion cells, or whether any cells without signal were obscured by signal in neighboring ganglion cells. There are displaced amacrine cells present in the ganglion cell layer; however, they are thought to be in low abundance (about $2.5 \%$ in goldfish [Tumosa and Stell, 1986]).

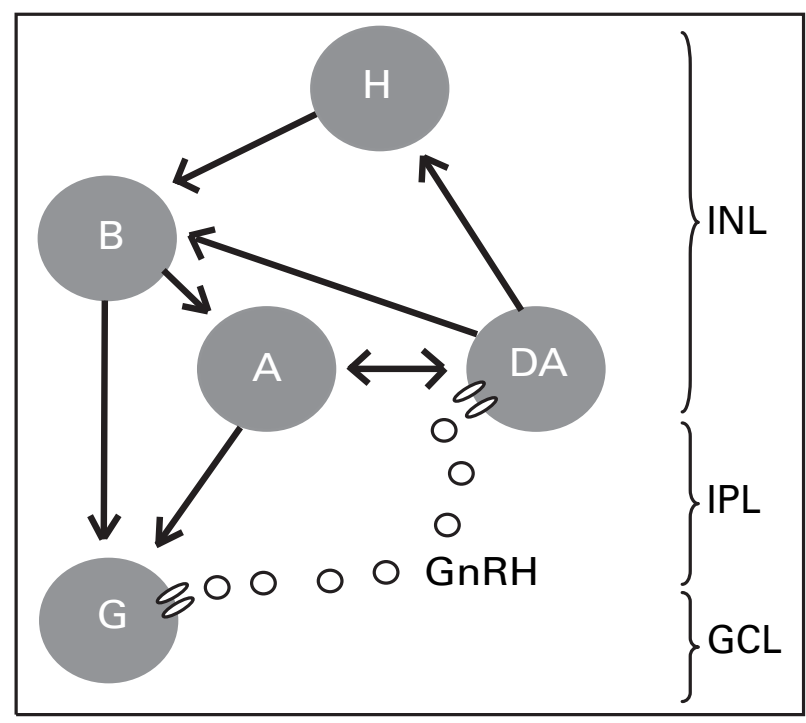

Fig. 5. Theoretical model of $\mathrm{GnRH}$ effects in retinal circuitry. GnRH reaches type 1 receptors in dopaminergic cells (DA) of the amacrine cell layer and type 2 receptors in ganglion cells $(G)$. Arrows indicate the direction of information between cells. Ganglion cells send information to the brain via the optic nerve. This model predicts that every cell type in the inner and ganglion cell layers may be affected by $\mathrm{GnRH}$. INL = Inner nuclear layer; IPL = inner plexiform layer; $\mathrm{GCL}=$ ganglion cell layer; $\mathrm{H}=$ horizontal cell; $\mathrm{B}=$ bipolar cell; $\mathrm{A}=$ amacrine cell.

It is likely that GnRH3 directly reaches cells possessing the type 1 receptor based on myriad evidence, including our own, that TN fibers course through the INL/IPL interface and based on descriptions of synaptic contacts between TN fibers and cells in this layer [Zucker and Dowling, 1987; Ball et al., 1989]. However, the anatomical connections between ganglion cells and TN fibers are less certain. Although there is evidence for GnRH immunoreactivity near ganglion cells [Stell et al., 1984] and displaced amacrine cells [Ball et al., 1989] in goldfish, we did not find GnRH-positive fibers near the GCL in A. burtoni. Immunolocalization of $\mathrm{GnRH}$ receptor type 2 protein on ganglion cells will resolve this issue.

Based on our findings it appears that many cell types of the INL and GCL may be affected - either directly or indirectly - by GnRH. In figure 5 we propose a conceptual model for how GnRH could have such widespread effects in the retina. Given the range of potential influences, it seems clear that GnRH delivered via the TN could modulate visual processing on a large scale. The multiple sites of $\mathrm{GnRH}$ influence on visual processing in the retina suggest that this neuromodulator has two important but different effects on visual processing. 
First, the GnRH type 1 receptor could impact the flow of lateral information in the retina via dopamine. The demonstration of the roughly uniform distribution of tyrosine hydroxylase-positive (i.e., dopaminergic, see fig. 3A) neurons hints that there would be widespread delivery of dopamine to its downstream targets. Thus, our data suggest that this pathway could deliver a broadly distributed neuromodulatory effect across the retina to affect the lateral processing of visual information. Dopamine has a considerable effect on visual processing in the retina, and is thought to play a critical role in light adaptation [Djamgoz and Wagner, 1992], spontaneous ganglion cell activity [see Iuvone, 1986 for review], modulating glutamate receptor sensitivity in horizontal cells [Knapp et al., 1990], and horizontal-horizontal and rod-cone cell coupling [Krizaj et al., 1998]. The evidence of widespread effects of dopamine on multiple aspects of visual processing suggests that $\mathrm{GnRH}$, acting on dopaminergic signaling, could indeed be an important neuromodulator of lateral information flow in the retina.
The second pathway described here involving GnRH type 2 receptors in ganglion cells suggests a more direct role of $\mathrm{GnRH}$ in visual processing. Because ganglion cells deliver visual information to the brain, a neuromodulator that affects their processing could have an immediate impact on retinal output. Indeed, the ubiquitous expression of GnRH-R2 mRNA in the ganglion cell layer hints that GnRH modulation could be a very important means of regulating retinal visual output. Taken together, these two mechanisms - lateral and vertical processing through which GnRH could influence retinal function might act in a complementary fashion to shape how and what an animal sees.

\section{Acknowledgements}

We gratefully acknowledge M. Corty, Dr. S. Halstenberg, R. Henderson, and M. Scanlon for technical help and comments on the manuscript. Funding was provided by NEI (05051) and NINDS J. Javits Award (NS 34950) to RDF and the Albion Walter Hewlett Stanford Graduate Fellowship to KEG.

\section{References}

Au T, Illing N, Fernald RD (2003) Social regulation of gonadotropin-releasing hormone receptor in the cichlid fish, Haplochromis burtoni. Soc Neurosci Abst 2003:611.6

Ball AK, Stell WK, Tutton DA (1989) Neurobiology of the inner retina. In: NATO ASI Series (Weiler R, Osborne NN, eds), pp 103-116. Berlin: Springer-Verlag.

Demski LS (1984) The evolution of neuroanatomical substrates of reproductive behavior - sex steroid and LHRH-specific pathways including the terminal nerve. Am Zool 24:809-830.

Demski LS (1993) Terminal nerve complex. Acta Anat 148:81-95.

Demski LS, Northcutt RG (1983) The terminal nerve: A new chemosensory system in vertebrates? Science 220:435-437.

Dowling JE, Ehinger B (1978) The interplexiform cell system. I. Synapses of the dopaminergic neurons of the goldfish retina. Proc R Soc Lond B 201:7-26.

Dubin MW (1974) Anatomy of the vertebrate retina. In: The Eye (Davson H, Graham LTJ, eds) pp 227-254. New York: Academic Press.

Dubois EA, Zandbergen MA, Peute J, Goos HJT (2002) Evolutionary development of three gonadotropin-releasing hormone (GnRH) systems in vertebrates. Brain Res Bull 57:413418.

Djamgoz M, Wagner H-J (1992) Localization and function of dopamine in the adult vertebrate retina. Neurochem int 20:139-191.
Eisthen HL, Northcutt RG (1996) Silver lampreys (Ichthyomyzon unicuspis) lack a gonadotropinreleasing hormone- and FMRFamide-immunoreactive terminal nerve. J Comp Neurol 370: 159-172.

Eisthen HL, Delay RJ, Wirsig-Wiechmann CR, Dionne VE (2000) Neuromodulatory effects of gonadotropin releasing hormone on olfactory receptor neurons. J Neurosci 20:3947-3955.

Fernald R, White R (1999) Gonadotropin-releasing hormone genes: phylogeny, structure, and functions. Neuroendocrinology 20:224-240.

Iuvone PM (1986) Neurotransmitters and neuromodulators in the retina: regulation, interactions, and cellular effects. In: The Retina (Adler R, Farber D, eds) pp 14-16. Orlando, FL: Academic Press.

- Jan YN, Jan LY, Brownfield MS (1980) Peptidergic transmitters in synaptic boutons of sympathetic ganglia. Nature 288:380-382.

- Kawamata K, Ohtsuka T, Stell WK (1990) Electron-microscopic study of immunocytochemically labeled centrifugal fibers in the goldfish retina. J Comp Neurol 293:655-664.

Knapp AG, Schmidt KF, Dowling JE (1990) Dopamine modulates the kinetics of ion channels gated by excitatory amino acids in retinal horizontal cells. Proc Natl Acad Sci 87:767-771.
Krizaj D, Gabriel R, Owen WG (1998) Dopamine $\mathrm{D}_{2}$ receptor-mediated modulation of rod-cone coupling in the Xenopus retina. J Comp Neurol 398:529-538.

- Lethimonier C, Madigou T, Munoz-Cueto J-A, Lareyre J-J, Kah O (2004) Evolutionary aspects of GnRHs, GnRH neuronal systems and GnRH receptors in teleost fish. Gen Comp Endocrinol 135:1-16.

Madigou T, Mananos-Sanchez E, Hulsof S, Anglade I, Zanuy S, Kah O (2000) Cloning, tissue distribution, and central expression of the gonadotropin-releasing hormone receptor in the rainbow trout (Oncorhynchus mykiss). Biol Reprod 63:1857-1866.

Malz CR, Jahn H, Meyer DL (1999) Centrifugal Phe-Met-Arg-Phe-NH2-like immunoreactive innervation of the retina in a non-teleost bony fish, Lepisosteus osseus. Neurosci Lett 264:3336.

Marc RE (1982) Spatial-organization of neurochemically classified interneurons of the goldfish retina.1.Local patterns. Vision Res 22: 589-608.

Munz H, Claas B, Stumpf WE, Jennes L (1982) Centrifugal innervation of the retina by luteinizing-hormone releasing hormone (LHRH)-immunoreactive telencephalic neurons in teleostean fishes. Cell Tissue Res 222:313-323.

- Oka Y (1992) Gonadotropin releasing-hormone $(\mathrm{GnRH})$ cells of the terminal nerve as a model neuromodulator system. Neurosci Lett 142 : 119-122. 
Robison RR, White RB, Illing N, Troskie BE, Morley M, Millar RP, Fernald RD (2001) Gonadotropin-releasing hormone receptor in the teleost Haplochromis burtoni: structure, location, and function. Endocrinology 142:1737-1743.

-Stell WK, Walker SE, Kuldip SC, Ball AK (1984) The goldfish nervous terminalis: a luteinizing hormone-releasing hormone and molluscan cardioexcitatory peptide immunoreactive olfactoretinal pathway. Proc Natl Acad Sci 81: 940-944.

- Tumosa N, Stell WK (1986) Choline-acetyltransferase immunoreactivity suggests that ganglion-cells in the goldfish retina are not cholinergic. J Comp Neurol 244:267-275.
Umino O, Dowling JE (1991) Dopamine release from interplexiform cells in the retina: Effects of GnRH, FMRFamide, bicuculine, and enkephalin on horizontal cell activity. J Neurosci 11:3034-3046.

Walker SE, Stell WK (1986) Gonadotropin-releasing hormone (GnRF), molluscan cardioexcitatory peptide (FMRFamide), enkephalin and related neuropeptides affects goldfish retinal ganglion cell activity. Brain Res 384:262-273.

White SA, Kasten TL, Bond CT, Adelman JP, Fernald RD (1995) Three gonadotropin-releasing hormone genes in one organism suggest novel roles for an ancient peptide. Proc Natl Acad Sci 92:8363-8367.
Wirsig-Wiechmann CR, Basinger SF (1988) FMRFamide-immunoreactive retinopetal fibers in the frog, Rana pipiens - demonstration by lesion and immunocytochemical techniques. Brain Res 449:116-134.

Zucker CL, Dowling JE (1987) Centrifugal fibres synapse on dopaminergic interplexiform cells in the teleost retina. Nature 330:166-168.

Zygar CA, Lee MJ, Fernald RD (1999) Nasotemporal asymmetry during teleost retinal growth: Preserving an area of specialization. J Neurobiol 41:435-442. 